\title{
Otomobil Sektöründe Tüketici Temelli Marka Değerinin Ölçümü Üzerine Bir Araştırma
}

\author{
Çağatan Taşkın ${ }^{\mathrm{a}}$
}

\begin{abstract}
Öz: Günümüzün tüketici odaklı pazarlarında, işletmeler pazar paylarını korumak ve arttırmak için, hedef kitlesinin belleğinde ayrıcalıklı bir yere sahip olmalıdır. Giderek artan ve çetinleşen rekabet koşulları işletmeleri markalaşma çabalarına daha fazla yatırım yapmaya zorunlu kılmaktadır. İşletmeler, algısal marka değerlerini, yazındaki yaygın adı ile tüketici temelli marka değerlerini en fazla etkileyen unsurları bulmak ve bu unsurları geliştirecek pazarlama stratejilerini oluşturmalı ve uygulamalıdır. Tüm sektörlerde olduğu gibi, otomobil sektöründe de yoğun bir rekabet söz konusudur. Otomobil markaları da algısal marka değerlerine en fazla katkı sağlayacak unsurları tespit ederek geliştirdiğinde, sürdürülebilir rekabetçi avantaj elde edebileceği değerlendirilmektedir. Bu çalışmanın amacı; Türkiye'de yoğun rekabetin yaşandığı otomobil sektöründe yer alan ve Bursa ilinde de üretim yapan yabancı bir otomobil markası için, tüketici temelli marka değeri ve boyutlarının ilişkisini "yapısal eşitlik modelleme" yaklaşımı ile araştırmak ve model sonuçlarına göre pazarlama stratejileri önermektir. Araştırmada kolayda örnekleme yöntemi kullanılmış olup, analiz için uygun 394 anket toplanmıştır. Elde edilen araştırma bulgularına göre, satış sonrası servis bileşeninin, algılanan kalite ve tüketici temelli marka değeri üzerinde; marka çağrışımları ve algılanan kalite bileşenlerinin marka bağlılığı üzerinde ve marka bağlılığının da tüketici temelli marka değeri üzerinde olumlu etkisi olduğu elde edilmiştir.
\end{abstract}

Anahtar Sözcükler: Tüketici Temelli Marka Değeri, Yapısal Eşitlik Modelleme, Satış Sonrası Servis, Otomobil Sektörü, Bursa

JEL Sınıflandırması: M30, M31

\section{A Research on the Measurement of Consumer Based Brand Equity in Automobile Sector}

Abstract: In today's consumer oriented markets, companies should have a privileged position in target markets' memories in order to preserve and increase their market shares. Increasing intense competition forces companies to invest on their brands more. Companies should know the dimensions that affect consumer based brand equity and should form strategies that can improve these dimensions. There is severe competition in automobile sector like in other sectors. Automobile companies are evaluated to have sustainable strategic advantage if they find the most important dimensions that affect consumer based brand equity and improve them. The aim of this study is to explore the relationships between consumer based brand equity of a foreign automobile brand, and its dimensions by means of structural equation modeling and to propose marketing strategies according to the modeling results. Convenience sampling method is used in the research and 394 questionnaires are collected for the analysis. According to the research findings, it is obtained that after sales service has a positive impact on perceived quality and consumer based brand equity; brand associations and perceived quality dimensions have a positive impact on the brand loyalty and brand loyalty has a positive impact on consumer based brand equity.

Keywords: Consumer Based Brand Equity, Structural Equation Modeling, After Sales Service, Automobile Sector, Bursa

JEL Classification: M30, M31

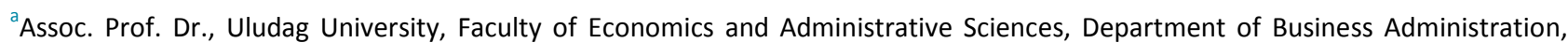
Bursa, Turkiye, ctaskin@uludag.edu.tr 


\section{Giriş}

Günümüzde tüketiciler, bilgi ve iletişim teknolojilerinin özellikle de mobil teknolojilerdeki gelişmeler sayesinde giderek daha farklı istek ve ihtiyaçları oluşan, dünyanın her yeri ile bağlantı kurmaya çalışan, daha hızlı marka değiştiren ve markalardan daha fazla ilgi bekleyen tüketiciler haline hızla dönüşmektedir. Bu durum da işletmeleri pazarlama stratejilerini kurgulama ve uygulama biçimlerini derinden etkilemektedir. İşletmeler daha fazla tüketici odaklı olmak durumunda kalmaktadır. Otomobil sektöründe yaşanan yoğun rekabet ve aynı pazar bölümleri içinde genel olarak otomobil markalarının birbirine benzerlik göstermesi, farklılaşmanın otomobillerin fiziksel unsurlarından çok satış öncesi ve daha da önemlisi satış sonrası müşterilerine sundukları deneyimlere kaymasına neden olmaktadır. Bu açıdan bakıldığında marka olmanın ve bu durumu sürdürmenin de zorlaştığı söylenebilir.

Bir markanın tüketiciye ifade ettiği anlam, belleğindeki ayrıcalıklı yer gibi öz bir ifade ile de tanımlanan "tüketici temelli marka değeri" (Aaker, 1996) işletmeler için vazgeçilmez olmanın anahtar unsurudur. Güçlü bir marka, tüketicinin ürüne ya da işletmeye karşı olan bağlılığının gücünü arttırır. Marka değerinin bu bakış açısından kavramsallaştırıması, pazarlama yöneticilerinin, tüketicilerin belleklerindeki değerlerini arttırmak için pazarlama stratejilerini nasıl oluşturacaklarına imkân sağlar. Güçlü bir marka; bir işletmeye, daha yüksek müşteri bağılığı, kriz durumlarına dayanmak için daha fazla esneklik, daha yüksek kar payları, fiyat değişikliklerine karşı daha olumlu müşteri tepkisi, lisans verme ve marka genişletme fırsatları gibi çeşitli faydalar sağlar. Bu gibi nedenlerden dolayı, tüketici bakış açısından marka değerinin ve boyutları arasındaki ilişkilerin incelenmesi etkin pazarlama stratejilerinin oluşturulmasında bir rehber olabileceği düşünülmektedir.

Otomobil sektöründe gerek Türkiye'de gerekse Türkiye'nin dördüncü büyük kenti olan Bursa ilinde pek çok otomobil markası rekabet halindedir. Yoğun rekabet işletmeleri daha etkin stratejiler oluşturmaya mecbur bırakmaktadır. Bu açıdan bakıldığında, işletmelerin tüketici temelli marka değerini etkileyen unsurları tespit etmesi ve bu unsurlar arasındaki ilişkileri iyi anlaması, stratejik avantaj sağlayabilir. Bu araştırmanın amacı; otomobil sektöründe faaliyet gösteren ve Bursa ilinde üretim yapan yabancı bir otomobil markası için, tüketici temelli marka değeri ve boyutları arasındaki ilişkileri "yapısal eşitlik modelleme" yaklaşımı ile ortaya koymak ve model sonuçlarına göre pazarlama stratejileri önermektir.

\section{Yazın Taraması}

Marka, bir satıcının ya da bir grup satıcının ürün ve hizmetlerini tanımlamak ve rakiplerinden farklılaştırmak için kullandığı, "bir isim, terim, sembol veya tasarım ya da bunların birleşimidir". Dolayısıyla bir marka, aynı ihtiyacı karşılamak üzere tasarlanan diğer ürün ve hizmetlerden unsurları farklılaşan bir ürün ya da hizmettir. Bu farklılıklar fonksiyonel, rasyonel veya somut olabilir. Ayrıca daha sembolik, duygusal ve soyut da olabilir (Kotler ve Keller, 2012:241).

Tüketici temelli marka değeri ise, markanın tüketiciye ifade ettiği değer veya markanın tüketici belleğindeki "algısal değer" olarak tanımlanabilir (Pappu, Quester ve Cooksey, 2005: 144). İlgili yazında önde gelen araştırmacılardan, Aaker ve Keller tüketicilerin bellek-temelli marka çağrışımlarına dayanan bir bakış açısından yola çıkarak marka değerini tanımlamışlardır. Keller, marka değerini tüketici temelli marka değeri olarak adlandırmış ve söz konusu kavramı, tüketicinin bir markanın pazarlanması faaliyetine verdiği tepki üzerinde marka bilgisinin fark etkisi olarak tanımlamıştır. Keller’e göre tüketici temelli marka değeri, marka bilgisi ve marka imajı olmak üzere iki boyuttan oluşmaktadır. Aaker'e göre tüketici temelli marka değeri, bir ürün ya da hizmet tarafından bir işletmeye ya da işletmenin müşterilerine sağlanan değeri arttıran veya azaltan, marka, marka adı ve marka sembolü ile ilişkili tüm varlıkların oluşturduğu bir kümedir. Aslında Aaker, marka değerini bir varlıklar kümesi olarak açıklamıştır. Marka bilinirliği, marka çağrışımları, algılanan kalite, marka bağlılı̆ı ve diğer mal sahibine ait varlıklar marka değerini oluşturan varlıklardır. Sözü edilen bu varlıklar boyutlar olarak da adlandırılmaktadır. Tüketici bakış açısından; marka bilinirliği, marka çağrışımları, algılanan kalite ve marka bağılığı marka değerinin dört önemli boyutu olarak kabul edilmektedir (Keller, 1993: 1-2; Keller, 2003: 3-5; Aaker, 1996: 103-104; Pappu vd., 2005: 144). 
Marka bilinirliği, tüketicilerin markayı tanımlayabilme veya tanıyabilme yeteneği olarak ifade edilebilir. Bir başka ifade ile marka bilinirliği tüketicinin aklına marka isminin gelmesi ile ilişkilidir. Marka bilinirliği, "marka tanıma" ve "marka hatırlama" bileşenlerinden oluşur. Marka tanıma, tüketicinin önceki bir deneyimi markada onaylayabilme yeteneği olarak açıklanabilir. Marka hatırlama ise, belli bir ürün kategorisi söz edildiğinde tüketicilerin, belleklerinden o markayı bulup ortaya çıkarabilme ya da markayı ve niteliklerini doğru bir şekilde hatırlayabilme yeteneğidir (Müller ve Chandon, 2003, s.211).

Marka çağrışımı ya da marka çağrışımları, bir marka ile ilgili bellekte yer alan herşeydir. Dolayısıyla, marka çağrışımları tüketicilerin satınalma kararlarını almada yardımcı olacak bilgilerin işlenmesini, organize edilmesini ve özümsenmesini kolaylaştırır. Tüketicilerin marka algılarının anlaşılması oldukça karmaşıktır. Bunun nedeni, marka çağrışımlarının çok boyutlu yapılarının birbirlerine benzemesidir (Kwun ve Oh, 2007, s.82-83).

Algılanan kalite ise, rakiplere kıyasla genel kalite ya da üstünlüğe ilişkin müşteri algılamasıdır. Bir başka ifade ile algılanan kalite, müşterilerin algılaması ile ilintilidir. Genellikle tüketiciler, belirli bir ürünü ya da hizmeti, kendi ürün sınıfının özellikler kümesi içinde değerlendirirler ve her özellik açısından farkı markaların nerede yer aldığına ilişkin algılar geliştirirler. Algılanan kalite, bir markaya ait soyut, genel duyguları içermesinin yanısıra, ürünün kendisine özgü özelliklerini vurgulayan ölçütleri de (güvenilirlik, performans, dayanıklılık gibi) kapsar (Atılgan, 2005, s.78-79).

Marka bağlılığı, durumsal etkilere ve tüketicinin satın alma kararının değişmesine yol açabilecek pazarlama çabalarının varlığına rağmen, bir ürünü tekrar satın alma davranışındaki kararlılık veya gelecekte ürünün sürekli müşterisi olma tercihi olarak tanımlanmıştır. Marka bağlıı̆̆ı, bir ürünün tekrar tercih edilme oranını arttırdığı ve pazarlama maliyetlerini düşürdüğü için oldukça önemli bir kavram olarak pazarlama yazınında yer almaktadır (Oliver, 1999:34).

Tüketici temelli marka değeri ölçümü konusundaki temel araştırmalara bakıldığında; Yoo ve Donthu (2001) adlı araştırmacıların, Aaker ve Keller'in ortaya koyduğu tüketici temelli marka değeri kavramını ölçmek için çok boyutlu bir ölçek geliştiren ilk araştırmacılar olduğu söylenebilir. Yoo, Donthu ve Lee (2000) adlı araştırmacılar; Aaker'in 1991 yılında, geliştirdiği kavramsal marka değeri modelini deneysel olarak test etmişlerdir. Aaker'in tanımladığı dört marka değeri boyutunu kullanarak, çok boyutlu bir tüketici temelli marka değeri ölçeği geliştirmişlerdir (Yoo, Donthu ve Lee, 2000: 195). Yoo ve Donthu adlı araştırmacıların geliştirdikleri tüketici temelli marka değeri ölçeğinin geçerliliği, daha sonra Washburn ve Plank adlı araştırmacılar tarafından da test edilmiştir (Washburn ve Plank, 2002: 46-47). Tüketici temelli marka değeri ölçeği geliştirme konusundaki temel araştırmalardan biri de Vazguez, Rio ve Iglesias adlı araştırmacılara ait 2002 yılında yayımlanan çalışmadır. Söz konusu ölçeğin, Türkiye'de uygulanabilirliğinin belirlenmesine yönelik Koçak ve Özer adlı araştırmacıların bir çalışması bulunmaktadır (Vazquez, Rio ve Iglesias, 2002: 27; Koçak ve Özer, 2004: 1).

Aaker'in; marka çağrışımları, marka bağ|ılığı, marka bilinirliği, algılanan kalite ve marka ile ilgili diğer varlıklar boyutlarından oluşan tüketici temelli marka değeri çerçevesi temel alınarak, Türkiye'de meşrubat sektöründe üniversite öğrencileri üzerinde marka değeri ölçümü ile ilgili bir çalışma da yapılmıştır. Bu çalışmada, marka bağlılı̆ı boyutunun marka değerini etkileyen en önemli unsur olduğu ortaya konmuştur (Atılgan, Aksoy ve Akıncı, 2005: 237). Marka değeri ölçümü üzerine yapılmış ve temel alınabilecek araştırmalardan bir diğeri, Pappu, Quester ve Cooksey adlı araştırmacılara aittir. Bu araştırmada, iki ayrı ürün kategorisi ve 6 ayrı marka değerlendirmeye tabi tutulmuştur (Pappu, Quester ve Cooksey, 2006: 696). Gene, Pappu ve Quester adlı araştırmacıların perakende markaları kullanarak yapmış oldukları marka değeri ölçümü çalışması, pazarlama yazınında oldukça yeni olan "perakendeci değeri" konusuna önemli bir katkıdır. Kullanılan tüketici temelli marka değeri ölçeği, Yoo ve Donthu'nun 2001 yılında yayımladıkları çalışmalarındaki ölçeğe benzerdir. Bu araştırmada, Avustralya'da büyük bir şehirde yaşayan 601 adet alışveriş merkezi tüketicisi denek olarak kullanılmıştır (Pappu ve Quester, 2006: 317). Yukarıda yapılan araştırmaların dışında tüketici temelli marka değeri ve ölçümü ile ilgili çeşitli yerli çalışmalar da mevcuttur (Avcılar, 2008; Marangoz, 2007; Çipli, 2008; Bursalı, 2007; Giray, 2009; Taşkın, 2008; Taşkın ve Akat, 2010; Toksarı ve inal, 2011). 
Çetinsöz ve Artuğer (2013) çalımasında, Türkiye'nin en önemli turizm destinasyonlarından biri olan Antalya'nın tüketici temelli marka değerinin ortaya çıkarılması amaçlanmıştır. Araştırma sonucunda, katılımcıların Antalya'nın marka değerine ilişkin görüşlerinin olumlu olduğu tespit edilmiş olup, en olumlu görüş "marka sadakati” faktörü için hesaplanmıştır. Ayrıca korelasyon analizi sonuçlarına göre, marka değeri boyutları arasında pozitif yönde orta seviyede bir ilişki olduğu tespit edilmiştir (Çetinsöz ve Artuğer, 2013:200).

Tüketici temelli marka değeri ve ölçümü ile ilgili bir başka çalışmada tüketici temelli marka değerini belirleyen ve etkileyen boyutların (algılanan kalite, marka bağlıı̆̆ı, marka farkındalığı ve marka çağrışımı) birbirleri ile olan ilişkileri ve hastane marka değerine olan etkilerinin, özellikle de algılanan kalitenin hastane marka değerine olan etkisi incelenmiştir. Hastane tüketici temelli marka değerinin, algılanan kalite, marka çağrışımı ve marka bağlıığı boyutları ile pozitif anlamlı bir ilişkiye sahip olduğu; marka çağrışımı, marka farkındalığı ve marka bağlılığı boyutlarının algılanan kaliteyi etkilediği ve ayrıca, bu üç boyutun etkisiyle algılanan kalitenin hastane marka değerine olan etkisinin daha arttığı tespit edilmiştir (Işık, 2016:57).

Yıldız (2015) çalışmasında, ağızdan ağıza iletişimin tüketici temelli marka değerinin alt boyutları olan marka farkındalı̆̆ı, marka çağrışımı, algılanan kalite ve marka sadakatine etkilerini araştırmıştır. Araştırma sonucunda; ağızdan ağıza iletişimin tüketici temelli marka değerinin bütün boyutları üzerinde pozitif yönde anlamlı etkileri olduğu gözlemlenmiştir. Aynı zamanda marka imajının; marka farkındalığı, marka çağrışımı ve marka sadakati boyutları üzerinde tam aracılık, algılanan kalite boyutu üzerinde de kısmi aracılık etkisine sahip olduğu belirlenmiştir (Yıldız, 2015:163).

Bir başka yerli çalışmada, marka farkındalığı, algılanan kalite, marka imajı ve marka bağıılığı ile tüketici temelli marka değeri arasındaki ilişkiler incelenmiştir. Ek olarak çalışma, kişisel bilgisayar sektöründe tüketici temelli marka değeri ile satın alma niyeti arasındaki ilişkiyi sınamaktadır. Sonuçlar, "algılanan kalite", "marka imajı", "marka farkındalığı" ve "marka bağlılığının” kişisel bilgisayar sektöründe tüketici temelli marka değerini olumlu yönde etkilediğini göstermiştir (Ural ve Perk, 2012:11).

Tüketici temelli marka değeri ölçümü ile ilgili genel araştırmaların dışında, bu çalışmanın sektörünü oluşturan otomobil markaları üzerinde yapılan araştırmalar mevcuttur. Örneğin bu alanda yapılan araştırmalardan biri Xiangxiang ve arkadaşlarına ait olup, Çin'de gerçekleştirilmiştir. Araştırmada özellikle marka bağlılı̆ını ve tüketici temelli marka değerini etkileyen faktörler tespit edilmiştir (Xiangxiang vd., 2011: 1). Çin otomobil markaları üzerinde yapılan bir başka araştırmada, tüketici temelli marka değerinin en önemli unsuru olarak kalite değişkeni bulunmuştur. Araştırma kartopu örnekleme yöntemi ile yapılmış olup, örneklem büyüklüğü 212'dir (Ye, 2012: 1). Gene Çin'de yapılan ve marka bağlıı̆ğının tüketici temelli marka değeri oluşturmada oldukça önemli bir etken olarak tespit edildiği bir diğer çalışma ise Mkhitaryan (2014)'e aittir(Mkhitaryan, 2014).

Amerika'da otomobil sektöründe yapılan bir araştırmada tüketici temelli marka değeri ile markanın pazar performansı arasındaki ilişki incelenmiş ve tüketici temelli marka değerinin markaların pazar performanslarına olumlu katkı sağladığı tespit edilmiştir (Kartono ve Rao, 2005: 4). Almanya'da on adet büyük otomobil markası için yapılan çalışmada, tüketici temelli marka değeri ile müşteri değeri arasındaki ilişkiler tespit edilmeye çalışılmıştır. Araştırma sonuçlarına göre marka çağrışımları tüketici temelli marka değeri açısından önemli bir rol oynamaktadır (Stahl ve Kirenz, 2009: 1).

Suudi Arabistan'da yapılan bir çalışmada, otomobil markaları için tüketici temelli marka değeri öncülleri araştırılmış ve marka bağlılı̆ının en önemli öncül olduğu tespit edilmiştir (Mahfooz, 2015: 81). Hindistan'da otomobil sektöründe yapılan tüketici temelli marka değeri ölçümü araştırmasında benzer şekilde marka bağlıı̆̆ının tüketici temelli marka değeri oluşturmada en önemli unsur olduğu ortaya konmuştur (Thiripurasundari ve Natarajan, 2011: 350). Aaker'in tüketici temelli marka değerini temel alan bir otomobil sektörü araştırmasında, marka bilinirliği, marka çağrışımları, algılanan kalite ve marka bağlıı̆̆ı unsurlarının tamamının tüketici temelli marka değeri oluşturmada önemli etkiye sahip oldukları ortaya konmuştur (Jalilvand vd., 2011: 149). Endonezya'da yapılan bir çalışmada, marka bilinirliği, marka çağrışımları, marka bağılı̆̆ı ve algılanan kalite unsurlarının, otomobil sektöründe tüketici temelli marka değerini güçlü bir şekilde etkilediği tespit edilmiştir (Murtiasih vd., 2013: 40). 
Yukarıda söz edilen araştırmaların dışında, Aaker'in temel dört boyuttan oluşan (marka bilinirliği, marka çağrışımları, algılanan kalite ve marka bağ|ılığı) "tüketici temelli marka değeri modeli"ne, aslında otomobil sektöründe son derece önemli olan satış sonrası servisin eklendiği bir çalışma da gerçekleştirilmiştir. Satış sonrası servis boyutunun da eklenerek modelin test edildiği bu çalışma Pakistan'da gerçekleştirilmiştir. Elde edilen araştırma bulgularına göre, satış sonrası servis değişkeninin tüketici temelli marka değeri oluşturmada önemli ve yakından ilişkili ancak ayrı bir boyut olduğu tespit edilmiştir. Otomobil sektöründe tüketici temelli marka değerini geliştirmek için satış sonrası servis boyutunun üzerine yoğunlaşılması gerektiği de vurgulanmıştır (Ahmad ve Butt, 2012: 307).

\section{Otomobil Sektöründe Tüketici Temelli Marka Değeri Ölçümü}

Türkiye'deki otomobil sektöründe rekabet giderek yoğunlaşmakta olup, etkin ve sürdürülebilir pazarlama stratejileri geliştirmek için tüketici temelli marka değeri ölçümüne olan gereksinim hızla artmaktadır. Bu çalışmada, Yoo ve Donthu (2001) adlı araştırmacıların geliştirdiği dört boyutlu "tüketici temelli marka değeri ölçeği" temel alınmış, mevcut ölçeğe Ahmad ve Butt (2012) adlı araştırmacıların çalışmasında olduğu üzere "satış sonrası servis" boyutu eklenmiştir.

\subsection{Araştırmanın Amacı ve Yöntemi}

Bu araştırmanın amacı; otomobil sektöründe faaliyet gösteren ve Bursa ilinde üretim yapan yabancı bir otomobil markası için, tüketici temelli marka değeri ve boyutları arasındaki ilişkileri "yapısal eşitlik modelleme" yaklaşımı ile ortaya koymak ve model sonuçlarına göre pazarlama stratejileri önermektir. Tüketici temelli marka değeri ve boyutları arasındaki ilişkilerin testi için yapısal eşitlik modelleme kullanılmıştır.

\subsection{Araştırmanın Evreni ve Örneklem Büyüklüğü}

Araştırmanın evrenini, Bursa il merkezinde yaşayan bireyler oluşturmaktadır. Türkiye i̇statistik Kurumu verilerine göre, Bursa il merkezinde, 2014 verilerine göre 1829482 kişi ikamet etmektedir (www.bursa.gov.tr). Araştırmanın evrenini temsil edecek örneklem büyüklüğ̈̈, $\% 5$ hata payı ile 384 olarak hesaplanmıştır (Kavak, 2013; Kaden, 2006). Araştırmada kolayda örnekleme yöntemi kullanılmıştır. Toplam olarak 446 anket verisi elde edilmiş olup, bunlardan 52 tanesi analize dâhil edilmemiştir. Analiz için 394 adet anket verisi kullanılmıştır.

\subsection{Araştırmanın Modeli ve Hipotezleri}

Şekil 1'de görülen araştırma modelinde "algılanan kalite", "marka bağlılı̆̆ı" ve "marka çağrışımları" Aaker'in kavramsal modelinden, "satış sonrası servis" değişkeni ise Ahmad ve Butt (2012) adlı araştırmacıların çalışmasından alınmıştır. Araştırma modelini oluşturan hipotezler ilgili yazındaki çeşitli araştırmalara dayanılarak oluşturulmuştur. Bunlara yazın taramasında değinilmiştir. Farklı olarak örneğin, Cai, Zhao ve He (2015) çalışmasında, algılanan kalite ve marka çağrışımlarının marka bağlıı̆̆ı üzerinde, marka bağlılı̆ının da tüketici temelli marka değeri üzerinde etkisini incelemiştir. Başka bir güncel çalışmada ise marka bağlıı̆̆ının tüketici temelli marka değeri üzerindeki etkisi araştııılmıştır (Seric, Gil-Saura ve Mikulic, 2016:1). Yazın taraması sonucunda, araştırmanın teorik modeli oluşturulmuştur ve Şekil 1'de verilmiştir. 
Şekil 1. Araştırma Modeli

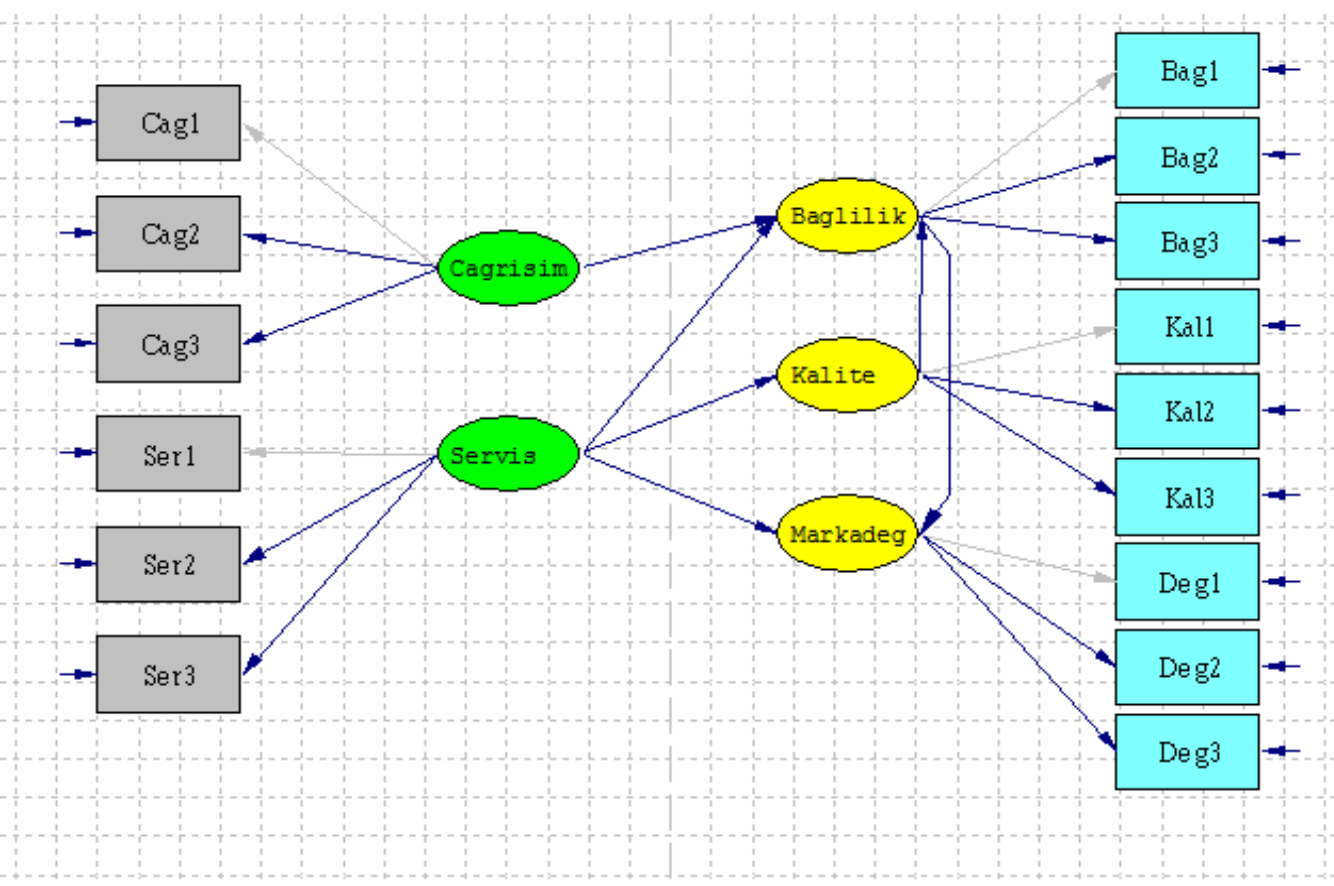

Araştırma hipotezleri ise, tüketici temelli marka değeri ile boyutları arasındaki ilişkileri ifade etmektedir. Araştırma hipotezleri Tablo 1'de verilmektedir.

Tablo 1. Araştırma Hipotezleri

\begin{tabular}{|c|c|}
\hline $\mathrm{H}_{1}$ & "Marka çağrışımları" boyutunun "marka bağ|ııı̆ı” üzerinde olumlu bir etkisi vardır. \\
\hline $\mathrm{H}_{2}$ & "Servis" boyutunun "marka bağ|ıı̆̆ı" üzerinde olumlu bir etkisi vardır. \\
\hline $\mathrm{H}_{3}$ & "Servis" boyutunun "algılanan kalite" üzerinde olumlu bir etkisi vardır. \\
\hline $\mathrm{H}_{4}$ & “Algılanan kalite" boyutunun "marka bağ|ıı̆ı̆” üzerinde olumlu bir etkisi vardır. \\
\hline $\mathrm{H}_{5}$ & "Servis" boyutunun "tüketici temelli marka değeri" üzerinde olumlu bir etkisi vardır. \\
\hline $\mathrm{H}_{6}$ & $\begin{array}{l}\text { "Marka bağıı̆ı̆ı” boyutunun "tüketici temelli marka değeri” üzerinde olumlu bir etkisi } \\
\text { vardır. }\end{array}$ \\
\hline
\end{tabular}

\subsection{Veri Toplama Yöntemi}

Anket iki kısımdan oluşmaktadır. Birinci kısımda katılımcıların demografik özelliklerine ilişkin (yaş, cinsiyet, medeni durum, gelir ve eğitim düzeyi) 5 adet soru, ikinci kısımda ise katılımcıların yabancı bir otomobil markasına dair algılarını ölçmek için kullanılan 15 adet ifade bulunmaktadır. Katılımcılardan bu ifadelere katılma derecelerini $5^{\prime}$ li Likert ölçeğinde (1=Kesinlikle katılmıyorum, 2=Katılmıyorum, 3=Kararsızım, 4=Katılıyorum, 5=Tamamen katılıyorum) işaretlemeleri istenmiştir. Veriler Aralık 2015 ile Ocak 2016 tarihleri arasında toplanmıştır. Toplamda 446 adet anket toplanmış olup, bunlardan 394 tanesi analiz için uygun bulunmuştur. 


\subsection{Güvenilirlik Analizi ve Açımlayıcı Faktör Analizi Sonuçları}

Toplanan veriler üzerinde güvenilirlik analizi ve açımlayıcı faktör analizi gerçekleştirilmiştir. Yapılan güvenilirlik analizi sonucunda, marka çağrışımları boyutunun Cronbach Alpha değeri 0,79 , satış sonrası servis boyutunun Cronbach Alpha değeri 0,80, marka bağlılığı boyutunun Cronbach Alpha değeri 0,76, algılanan kalite boyutunun Cronbach Alpha değeri 0,79 , tüketici temelli marka değeri boyutunun Cronbach Alpha değeri 0,71 ve ölçeğin bir bütün olarak Cronbach Alfa değeri 0,83 olarak bulunmuştur. Ölçekte yer alan ifadelerin, teorik model ile varsayılan faktörler altında toplanıp toplanmadıklarını test etmek için yapılan faktör analizi ile ilgili bilgiler Tablo 2 ve Tablo 3'te görüldüğü gibidir. Toplam beş faktörün açıklanan varyans oranı yüzde 70,561 'dir.

Tablo 2. KMO ve Bartlett Test Sonuçları

\begin{tabular}{|c|c|c|}
\hline \multicolumn{2}{|c|}{ Kaiser-Meyer-Olkin Measure of Sampling Adequacy. } & ,776 \\
\hline \multirow{3}{*}{ Bartlett's Test of Sphericity } & Approx. Chi-Square & 1345,229 \\
\hline & df & 120 \\
\hline & Sig. &, 000 \\
\hline
\end{tabular}

Yapılan açımlayııı faktör analizi sonuçlarına aşağıda Tablo 3'te yer verilmektedir. Görüleceği üzere, toplam 5 faktör oluşmuştur. Burada yer alan birinci faktör "algılanan kalite", ikinci faktör "satış sonrası servis", üçüncü faktör "marka bağlıığı", dördüncü faktör "marka çağrışımları" ve beşinci faktör "tüketici temelli marka değeri" grubunu oluşturan ifadelerdir.

Tablo 3. Döndürülmüş Faktör Matrisi

\begin{tabular}{|l|c|c|c|c|c|}
\hline \multirow{2}{*}{} & \multicolumn{5}{|c|}{ Faktörler } \\
\cline { 2 - 6 } & 1 & 2 & 3 & 4 & 5 \\
\hline Cag1 & & & &, 723 & \\
Cag2 & & & &, 765 & \\
Cag3 & & & &, 821 & \\
Ser1 & &, 847 & & & \\
Ser2 & &, 751 & & & \\
Ser3 & &, 855 & & & \\
Bag1 & & &, 729 & & \\
Bag2 & & &, 764 & & \\
Bag3 & & &, 752 & & \\
Kal1 &, 661 & & & & \\
Kal2 &, 740 & & & & \\
Kal3 &, 778 & & & &, 742 \\
Deg1 & & & & & \\
Deg2 & & & & &, 783 \\
Deg3 & & & & & \\
\hline
\end{tabular}

Extraction Method: Principal Component Analysis.

Rotation Method: Varimax with Kaiser Normalization. 


\subsection{Araştırmanın Bulguları}

Bu bölümde frekans analizi ve oluşturulan yapısal modelin test edilmesiyle ilgili test sonuçları yer almaktadır. Katılımcılara ilişkin demografik bilgiler Tablo 4'te gösterilmiştir.

Tablo 4. Katılımcıların Demografik Bilgileri

\begin{tabular}{|c|c|c|c|c|c|}
\hline Cinsiyet & Sıklık & Yüzde & Medeni Durum & Sıklık & Yüzde \\
\hline Kadın & 202 & 51.3 & Evli & 167 & 42.4 \\
\hline Erkek & 192 & 48.7 & Bekâr & 227 & 57.6 \\
\hline Toplam & 394 & 100 & Toplam & 394 & 100 \\
\hline Yaş & Sıklık & Yüzde & Eğitim Durumu & Sıklık & Yüzde \\
\hline $18-24$ & 72 & 18.3 & İlköğretim & 11 & 2.8 \\
\hline $25-34$ & 147 & 37.3 & Lise & 83 & 21.1 \\
\hline $35-44$ & 106 & 26.9 & Üniversite & 220 & 55.8 \\
\hline $45-54$ & 53 & 13.5 & Lisansüstü & 80 & 20.3 \\
\hline $55-64$ & 12 & 3.0 & Toplam & 394 & 100 \\
\hline 65 ve üzeri & 4 & 1.0 & Gelir & Sıklık & Yüzde \\
\hline \multirow[t]{5}{*}{ Toplam } & 394 & 100 & 1300 TL'den az & 102 & 25.9 \\
\hline & & & $1300-3000$ TL arası & 196 & 49.7 \\
\hline & & & 3001-5000 TL arası & 68 & 17.3 \\
\hline & & & 5000 TL üzeri & 28 & 7.1 \\
\hline & & & Toplam & 394 & 100 \\
\hline
\end{tabular}

Araştırma modelinde yer alan örtük değişkenler arasındaki yapısal ilişkileri açıklayan model Lisrel 8.71 paket programı kullanılarak oluşturulmuştur. Elde edilen yapısal model ve standardize çözüm değerleri Şekil 2'de verilmektedir.

Şekil 2. Yapısal Model: Standardize Çözüm Değerleri

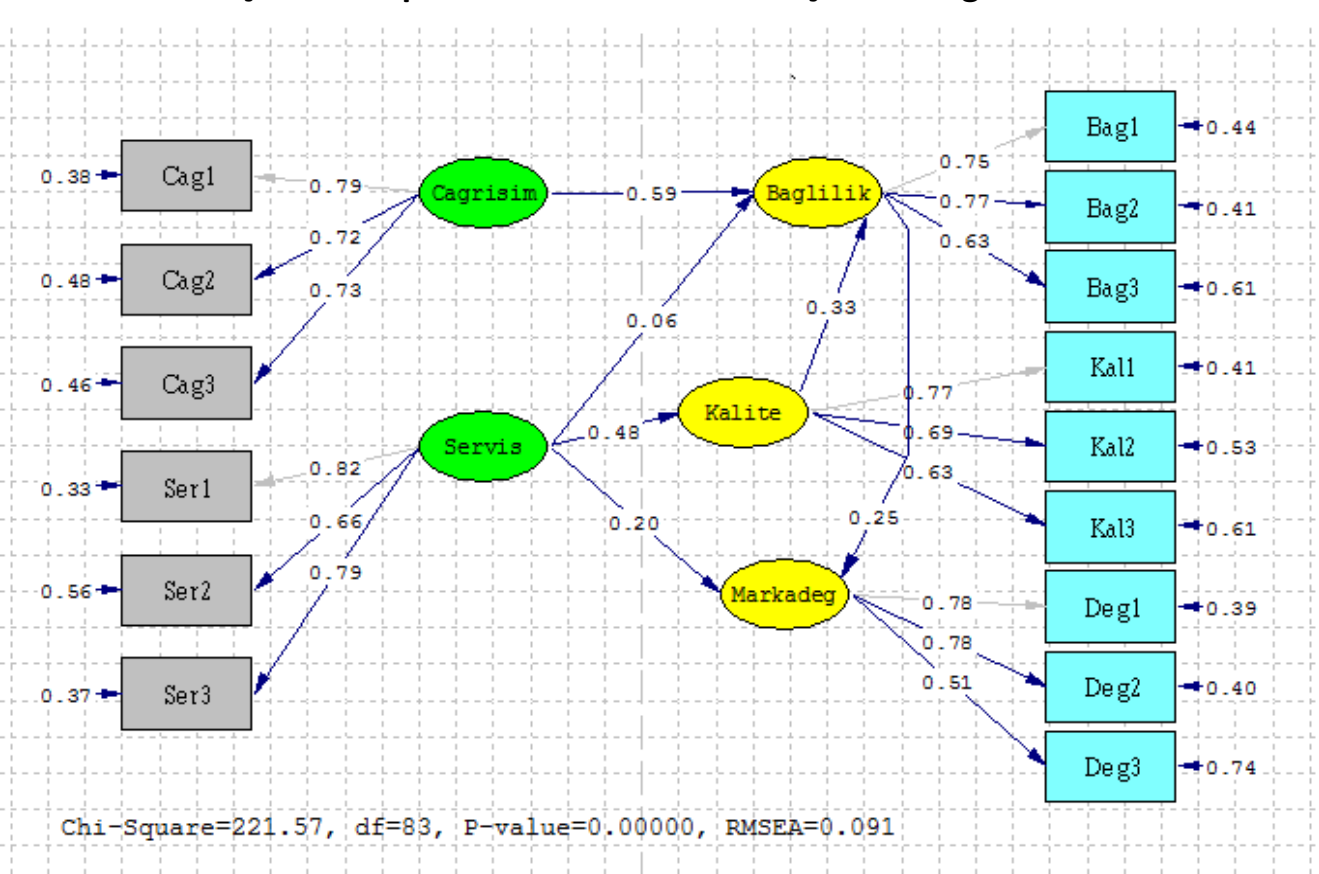


Tablo 5. Standardize Çözüm Değerleri, T Değerleri ve Hipotez Sonuçları

\begin{tabular}{|c|c|c|c|c|c|}
\hline $\begin{array}{l}\frac{\grave{d}}{N} \\
\stackrel{0}{0} \\
\frac{0}{1}\end{array}$ & Yollar & 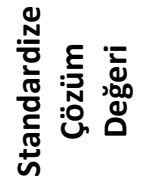 & $\begin{array}{c}\text { t-değeri } \\
* p<0.05 \\
* * p<0.01\end{array}$ & Sonuçlar & Açıklanma Değeri \\
\hline $\mathrm{H}_{1}$ & Marka çağrışımları-Marka bağlılığı & 0.59 & $6.15^{* *}$ & Desteklendi & $\mathrm{R}_{\text {marka bağll|l̆ğl }}^{2}=0.58$ \\
\hline $\mathrm{H}_{2}$ & Servis-Marka Bağıılığı & 0.06 & 0.65 & Desteklenmedi & $\mathrm{R}_{\text {algilanan kalite }}^{2}=0.23$ \\
\hline $\mathrm{H}_{3}$ & Servis-Algılanan kalite & 0.48 & $5.15^{* *}$ & Desteklendi & $\mathrm{R}_{\text {marka değeri }}^{2}=0.15$ \\
\hline $\mathrm{H}_{4}$ & Algılanan kalite-Marka bağlılı̆ı & 0.33 & $3.41^{* *}$ & Desteklendi & \\
\hline $\mathrm{H}_{5}$ & Servis-Tüketici temelli marka değeri & 0.20 & $2.02^{*}$ & Desteklendi & \\
\hline $\mathrm{H}_{6}$ & $\begin{array}{c}\text { Bağ|ılık-Tüketici temelli marka } \\
\text { değeri }\end{array}$ & 0.25 & $2.42^{*}$ & Desteklendi & \\
\hline
\end{tabular}

Şekil 2 ve bir özet olarak verilen Tablo 5 'teki t değerleri incelendiğinde $\mathrm{H}_{2}$ haricindeki tüm hipotezlerin desteklendiği görülmektedir. Elde edilen yapısal modelde; marka çağrışımının marka bağlılığını $(\beta=0,59 ; p<0,01)$, satış sonrası servisin algılanan kaliteyi $(\beta=0,48 ; p<0,01)$, algılanan kalitenin marka bağlııı̆ını $(\beta=0,33 ; p<0,01)$, marka bağlılığının tüketici temelli marka değerini $(\beta=0,25 ; p<0,05)$ ve satış sonrası servisin tüketici temelli marka değerini $(\beta=0,20 ; p<0,05)$ etkilediği gözlemlenmiştir. Sonuçlara bakıldığında; satış sonrası servis hizmetlerinin sözkonusu otomobil markası için kalite algısı ve tüketici temelli marka değeri oluşturmada önemli bir etkiye sahip olduğu söylenebilir. Ayrıca, marka çağrışımlarının da marka bağlılığı oluşturmada çok önemli bir etkisi ortaya çıkmıştır. Elde edilen yapısal modelin uyum iyiliği değerleri de Tablo 6 'te verilmektedir.

Tablo 6. Yapısal Model İçin Uyum İyiliği İstatistikleri

\begin{tabular}{|lll|}
\hline $\begin{array}{c}\text { Uyum İyiliği } \\
\text { İstatistikleri }\end{array}$ & $\begin{array}{c}\text { Iyi Uyum / Kabul } \\
\text { Edilebilir Uyum Değer } \\
\text { Aralı̆̆ }\end{array}$ & $\begin{array}{l}\text { Yapısal Modelin } \\
\text { Değerleri }\end{array}$ \\
\hline Chi-Square/df & $<2 /<5$ & $(221.57 / 83)=2.66$ \\
\hline GFI & $>0.95 />0.90$ & 0.91 \\
\hline AGFI & $>0.90 />0.85$ & 0.87 \\
\hline CFI & $>0.95 />0.90$ & 0.97 \\
\hline RMSEA & $<0.05 /<0.10$ & 0.09 \\
\hline RMR & $<0.05 /<0.10$ & 0.04 \\
\hline SRMR & $<0.05 /<0.10$ & 0.04 \\
\hline
\end{tabular}

Elde edilen yapısal modele ait uyum iyiliği istatistiklerine bakıldığında, bazıları iyi uyum değer aralı̆ıında bazıları ise kabul edilebilir uyum değer aralığındadır (Şimşek, 2007). 


\subsection{Araştırma Sonuçlarının Değerlendirilmesi}

Elde edilen yapısal modeldeki yol katsayılarının büyüklüğüne bakıldığında, "satış sonrası servis" "algılanan kalite" - "marka bağ|lığı" - "tüketici temelli marka değeri" yolunun oldukça önemli olduğu söylenebilir. Bir başka ifade ile söz konusu markanın servis durumunun (gözlenebilir değişkenler: servis ağının geniş olması, yedek parçasının kolay bulunması, servis elemanlarının nitelikli olması) algılanan kalite üzerinde önemli bir etkiye sahip olduğu saptanmıştır. Algılanan kalite bileşeninin de marka bağlılığ ve marka bağlıığının da tüketici temelli marka değeri üzerinde etkisi gözlemlenmiştir. Bu bulgudan hareketle, otomobil sektöründe faaliyet gösteren işletmeler için servis hizmetlerinin yaygınlığı ve kalitesinin son derece önemli olduğu söylenebilir. Servis hizmetlerinin yüksek kaliteli olması ve algılanması için, servis hizmetlerinde çalışanlara öncelikle, genelde "pazarlama" özelde "müşteri ilişkileri yönetimi" eğitimleri verilmesinde yarar vardır. Dolayısıyla, önerilebilecek temel pazarlama stratejisi, etkin işleyen bir müşteri ilişkileri ve müşteri şikâyet yönetimi sisteminin oluşturulmasıdır. Yapısal model sonuçlarından anlaşılacağı üzere, kullanıcıların otomobil markasına yönelik olumlu ya da olumsuz düşünceleri servis hizmetlerinin nicelik ve niteliğine göre değişebilmektedir. Satış sonrası servis bileşeni ile algılanan kalite bileşeni arasındaki yapısal ilişkinin 0,48 gibi oldukça yüksek bir değer olması nedeniyle bu çıkarımda bulunulabilir. Etkin işleyen bir müşteri ilişkileri yönetimi sisteminin işletmenin ürün stratejilerine katkısı da olacaktır. Ürün ile ilgili geri bildirimlerin işletmeye daha düzenli ve etkin iletilmesi, tasarım faaliyetlerine de yön verecektir. Müşteri ilişkileri yönetim sistemi ile müşteriler hakkındaki gerekli tüm bilgiler bir veri tabanında olacağından, çeşitli veri madenciliği yöntemleri ile müşterilerin satın alma davranışları incelenebilir. Ayrıca hizmet stratejilerini geliştirmek için, hizmet detay planı (blueprinting) çalışmaları yapılabilir. Bu tip çalışmalar, işletmenin hedef kitlesine daha tutarlı ikna mesajları göndermesinde yararlı olacaktır.

Elde edilen yapısal model sonuçları içinde bir başka önemli bulgu "marka çağrışımları" bileşeninin "marka bağlıı̆ı"” bileşeni üzerindeki etkisidir. Elde edilen bulgulara göre, "marka çağrışımları" marka bağlılı̆ı üzerinde pozitif bir etkiye sahiptir ve standardize edilmiş yol katsayısı 0.59 'dur. "Bir marka ile ilgili bellekte yer alanlar" olarak tanımlanan "marka çağrışımları" özellikle "tutundurma" ile ilişkilidir. Otomobil markaları için kullanılan yaygın tutundurma yöntemleri TV reklâmları ve otomobil fuarlarıdır. Ancak, hedef kitleye ikna mesajlarının yalnızca bu iki tutundurma aracı üzerinden gittiğini söylemek oldukça eksik olacaktır. Otomobil satış bayileri özellikle hedef kitle ile yüzyüze temasın sağlandığı en etkili yerlerdir. Elbette ki TV reklamlarının dikkat çekici olması, ilgi uyandırması, arzu yaratması ve satın almaya yöneltmesi gerekir. Bununla beraber, otomobil satış bayilerinde çalışan satış elemanlarının hedef kitleyi önemli bir etkileme gücü vardır. Eğer otomobil markaları hedef kitleleri ile fiziksel temas kurdukları her anda hedef kitlelerine "olumlu ve hatırda kalıcı deneyimler" yaşatabilirse gerçek anlamda fark yaratmış olacaktır. Elde edilen yapısal modelin sonuçları da özellikle satış sonrası servis hizmetinin önemini vurgulamıştır. Müşterilerine, satış sonrası servis hizmetlerinde sıradan olmayan, bellekte kalıcı olan ve aynı zamanda ağızdan ağıza iletişim ve veya viral iletişim etkisi oluşturan deneyimler yaşatmaya dayalı pazarlama stratejilerinin otomobil sektöründe tüketici temelli marka değerine olumlu katkı sağlayacak stratejiler olduğu söylenebilir.

\section{Sonuç}

Bu çalışmada; Türkiye'de otomobil sektöründe faaliyet gösteren ve Bursa ilinde üretim yapan yabancı bir marka için, tüketici temelli marka değeri ve bileşenleri arasındaki ilişkiler "yapısal eşitlik modelleme" yaklaşımı ile araştırımıştır. Ayrıca; elde edilen model sonuçlarının söz konusu işletmenin etkin pazarlama stratejileri geliştirmede bir karar destek aracı olarak nasıl kullanabileceği, pazarlama strateji önerileri ile gösterilmiştir. Araştırma sonuçları, tüketici temelli marka değeri ile her bir bileşeni arasındaki ilişkilerin birbirinden oldukça farklı olduğunu ortaya koymuştur. Özellikle, satış sonrası servis bileşeninin algılanan kalite bileşeni üzerinde önemli bir etkisi tespit edilmiştir. Satış sonrası servis bileşeni, algılanan kalite bileşenini etkilemekte ve algılanan kalite bileşeni de marka bağııığını etkilemektedir. Marka bağılığı bileşeni de tüketici temelli marka değerini etkilemektedir. Dolayısıyla, söz konusu işletme markasının tüketici temelli marka değerinin olumlu olarak etkilenmesi için, söz konusu markaya olan bağlıı̆ın artması yönünde çalışmaların yapılması gerekmektedir. Yapısal ilişkilerin büyüklükleri göz önüne alındığında, 
özellikle marka çağrışımları, satış sonrası servis ve satış sonrası hizmetlere odaklanan pazarlama stratejilerinin, işletmenin tüketici temelli marka değerine olumlu katkı sağlayacağı söylenebilir.

Hemen her araştırmada olduğu gibi, yapılan bu araştırmanın da bazı sınırlamaları mevcuttur. Araştırma Bursa il merkezinde ve bir yabancı otomobil markası için yapılmıştır. Araştırmada kullanılan örnekleme yöntemi kolayda örneklemedir. Dolayısıyla, elde edilen model sonuçları genelleştirilemez. Bunun yanı sıra, ilgili yazında, tüketici temelli marka değerinin teorik yapısını birbirinden farklı bakış açıları ile anlatan çeşitli teorisyenler mevcuttur. Bu teorik çerçevelerden en yaygın olarak kabul göreni Aaker adlı araştırmacıya aittir. Bu araştırmada da temel alınan teorik çerçeve Aaker adlı araştırmacının ortaya koyduğu yapıdır. Aaker'in ortaya koymuş olduğu bileşenlere Ahmad ve Butt adlı araştırmacıların çalışmasından hareketle satış sonrası servis bileşeni eklenmiştir. Son yıllarda, tüketici temelli marka değeri çalışmalarında Aaker'in önerdiği ve yaygın kabul gören dört bileşenin dışında, satış sonrası servis bileşenin de eklenmesi gerektiği vurgulanmaktadır. Ancak, bu konudaki alan araştırmaları yetersizdir. Gelecekte özellikle otomobil sektöründe yapılacak araştırmaların satış sonrası servis bileşeni ile birlikte başka bileşenlerin de araştırma kapsamına dâhil etmesi, ilgili yazını geliştirecektir.

\section{Kaynaklar}

Aaker, D. A. (1996). Measuring brand equity across products and markets. California Management Review, 38(3), 102120.

Ahmad, S., \& Butt, M. M. (2012). Can after sale service generate brand equity?. Marketing Intelligence \& Planning, 30(3), $307-323$.

Atılgan, E. Aksoy, Ş., \& Akıncı, S. (2005). Determinants of the brand equity: A verification approach in the beverage industry in Turkey. Marketing Intelligence \& Planning, 23(3), 237-248.

Avcılar, M.Y. (2008). Tüketici temelli marka değerinin ölçümü. Ç.Ü. Sosyal Bilimler Enstitüsü Dergisi, 17(1), 11-30.

Bursalı, O.B. (2007). Marka değerinin tespiti ve Denizli tekstil sektörü üzerinde uygulanması. Gazi Üniversitesi Sosyal Bilimler Enstitüsü, Yayımlanmamış Doktora Tezi, Ankara.

Cai, Y., Zhao, G., \& He, J. (2015). Influences of two modes of intergenerational communication on brand equity. Journal of Business Research, 68, 553-560.

Çetinsöz, B.C., \& Artuğer, S. (2013). Antalya ilinin marka değerinin ölçülmesine yönelik bir araştırma. Anatolia: Turizm Araştırmaları Dergisi 24(2), 200-210.

Çipli, Ç. (2008). Pazarlama karması elemanlarının marka değeri üzerine etkisi. Gebze Yüksek Teknoloji Enstitüsü, Yayımlanmamış Yüksek Lisans Tezi, Kocaeli.

Jalilvand, M. R., Samiei, N., \& Mahdavinia, S.H. (2011). The effect of brand equity components on purchase intention: An application of Aaker's Model in the automobile industry. International Business and Management, 2(2), 149158

Giray, N. (2009). Marka stratejisi kararları ve marka stratejilerinin marka değeri itibarıyla farkııı̆ıı: Ankara ili örneği, Gazi Üniversitesi Eğitim Bilimleri Enstitüsü, Yayımlanmamış Yüksek Lisans Tezi, Ankara.

Işık, O. (2016). Algılanan kalitenin hastane marka değerine etkisi. Hacettepe Sağlık idaresi Dergisi, 19(1), 57-72.

Kaden, R. J. (2006). Guerrilla marketing research: Marketing Research techniques that can help any business make more money. USA: Kogan Page.

Kartono, V., \& Rao, R. (2005). Linking consumer-based brand equity to market performance: An integrated approach to brand equity management. Working paper.

Kavak, B. (2013). Pazarlama ve pazar araştırmaları: Tasarım ve analiz. Ankara: Detay Yayıncılık.

Keller, K.L. (1993). Conceptualizing, measuring and managing customer-based brand equity. Journal of Marketing, $57(1), 1-22$

Keller, K.L. (2003). Strategic brand management: Building, measuring and managing brand equity. USA: Prentice-Hall.

Koçak, A., \& Özer, A. (2004). Marka değeri belirleyicileri: Bir ölçek değerlendirmesi. 9.Ulusal Pazarlama Kongresi, Ankara, 1-15.

Kotler, P., \& Keller, K.L. (2012). Marketing management. USA: Prentice-Hall. 
Kwun, D.J.W., \& Oh, H. (2007). Consumers' evaluation of brand portfolios. International Journal of Hospitality Management, 26(1), 81-97.

Marangoz, M. (2007). Tüketici davranışı temeline göre marka değerinin ölçülmesine yönelik bir araştırma. Marmara Üniversitesi Öneri Dergisi, 7(28), 87-96.

Müller, B., \& Chandon, J.L. (2003). The impact of visiting a brand website on brand personality. Electronic Markets, 13(3), 210-221.

Mahfooz, Y. (2015). Brand equity-consequence relationship: Evidence from Automobile industry. International Journal of Business and Management, 10(3), 81-90.

Mkhitaryan, D. (2014). Determinants of brand equity in automobile producing companies in China. Journal of Business Administration Research, 3(1).

Murtiasih, S. Sucherly, Siringoringo, H. (2013). How word of mouth influence brand equity for automotive products in Indonesia. Procedia - Social and Behavioral Sciences, 81, $40-44$.

Oliver, R. (1999). Whence consumer loyalty?. Journal of Marketing, 63, 33-44.

Pappu, R., Quester, P.G., \& Cooksey, R.W. (2005). Consumer-based brand equity: Improving the measurement empirical evidence. Journal of Product \& Brand Management, 14(3), 143-154.

Pappu, R., Quester, P.G., \& Cooksey, R.W. (2006). Consumer-based brand equity and country-of-origin relationships: Some empirical evidence. European Journal of Marketing, 40(5/6), 696-717.

Pappu, R., \& Quester, P. (2006). A Consumer-based method for retailer equity measurement: Results of an empirical study. Journal of Retailing and Consumer Services, 13(5), 317-329.

Šerić, M. Gil-Saura, I., \& Mikulić, J. (2016). Customer-based brand equity building Empirical evidence from Croatian upscale hotels. Journal of Vacation Marketing, 1-12.

Stahl, F., \& Kirenz, J. (2009). The impact of customer-based brand equity on customer equity: the case of the automobile industry. INFORMS Marketing Science, Ann Arbor, 1-2.

Şimşek, Ö.F. (2007). Yapısal eşitlik modellemesine giriş- Temel ilkeler ve Lisrel uygulamaları. Ankara: Ekinoks Yayınevi.

Taşkın, Ç. (2008). Pazarlama stratejilerinin oluşturulmasında marka değerinin etkisi ve bir uygulama. Uludağ Üniversitesi Sosyal Bilimler Enstitüsü, Yayımlanmamış Doktora Tezi, Bursa.

Taşkın, Ç. \& Akat, Ö. (2010). Tüketici temelli marka değerinin yapısal eşitlik modelleme ile ölçümü ve dayanıklı tüketim malları sektöründe bir araştırma. Business and Economics Research Journal, Vol:1, No:2.

Toksarı, M., \& Inal, M.E. (2011). Tüketici temelli marka değerinin ölçümü: kayseri'de otomobil kullanıcıları üzerine bir uygulama. Çağ University Journal of Social Sciences, 8(2), 69-97.

Ural, T., \& Perk. H.G. (2012). Tüketici temelli marka değerinin kişisel bilgisayar satın alma niyeti üzerine etkisi: Antakya'da bir çalışma. Anadolu Üniversitesi Sosyal Bilimler Dergisi, 12(3), 11-26.

Thiripurasundari, U. \& Natarajan, P. (2011). Determinants of brand equity in Indian car manufacturing firms. International Journal of Trade, Economics and Finance, 2(4), 346-350.

Vazquez, R. Rio, A. B.d., \& Iglesias, V. (2002). Consumer-based brand equity: Development and validation of a measurement instrument. Journal of Marketing Management, 18(1-2), 27-48.

Washburn, J.H., \& Plank, R. E. (2002). Measuring brand equity: An evaluation of a consumer-based brand equity scale. Journal of Marketing Theory and Practice, Winter, 46-61.

Xiangxiang, Z., Guoqin, B., Shuzhen, W., \& Qiongsen, X. (2011). Research on brand equity of automobile Industry Based on customer experience and modern service. Management and Service Science International Conference, 2011, $1-4$.

www.bursa.gov.tr.

Ye, L. (2012). Country of origin and customer-based brand equity: A quantitative study on Chinese cars going global. Marketing Master's Thesis, Aalto University School of Economics.

Yıldız, E. (2015). Ağızdan ağıza iletişimin tüketici temelli marka değeri boyutlarına etkileri: Marka imajının aracılık rolü. Business and Economics Research Journal, 6(3), 163-181.

Yoo, B., \& Donthu, N. (2001). Developing and validating a multidimensional consumer-based brand equity scale. Journal of Business Research, 52(1), 1-14.

Yoo, B., Donthu, N., \& Lee, S. (2000). An examination of selected marketing mix elements and brand equity. Journal of the Academy of Marketing Science, 28(2), 195-211. 